\title{
The Process of Going/Settling on the Streets: The Relations between Gender, Being Homeless and Access the Health Services
}

\author{
Dalvan Antônio de $\operatorname{Campos}^{1} \&$ Rodrigo Otávio Moretti-Pires ${ }^{1}$ \\ ${ }^{1}$ Public Health Department, Federal University of Santa Catarina, Santa Catarina, Brazil \\ Correspondence: Dalvan Antônio de Campos, School of Management, Public Health Department, Federal \\ University of Santa Catarina, Florianópolis, Santa Catarina, Brazil. Tel: +55-483-721-4869. E-mail: \\ dalvandecampos@gmail.com
}

Received: December 3, 2021 Accepted: February 7, 2022 Online Published: February 17, 2022

doi:10.5539/gjhs.v14n3p77 URL: https://doi.org/10.5539/gjhs.v14n3p77

\begin{abstract}
The objective of this article was to understand the relationship between gender constructions and the process of going/settling on the streets, as well as their effects on access to health services for homeless people in the city of Florianópolis/SC. Gender relations were analyzed in the trajectories of 28 gay, lesbian and heterosexual homeless people in the city of Florianópolis/SC/Brazil, based on a social constructionism research developed from December 2017 to February 2018. Family conflicts and non-acceptance of the gender identities were narrated as a fuse of going to the street and as aggravating for violence situations in the street context. The stigma for being homeless and non-heterosexual was understood as an obstacle to the use of health and social services. It is concluded that gender relations and male domination are related to the process of breaking of family ties and going to the street. Women and LGBT people are more vulnerable. Heterosexual men suffer for maintenance their dominant position. Further studies are recommended to deepen the relationship between gender, homeless and access to public policies.
\end{abstract}

Keywords: Gender identity, homeless persons, violence

\section{Introduction}

Sexuality is a contemporary prominence theme and a complex field, with competing narratives in the scientific scenario. Foucault (1979) points out that its regulation in the West emerges as an effect of the foundation of modern episteme in the 18th century, which shifted the centrality of the sexual act to the desire and constitution of the subject. The discourses and social practices produce men and women make the central theme in social investigations.

This social construction perspective gained visibility with the emergence of the feminist movement and the concept of gender - social constructions, ways of being and acting performed and reiterated individually according to their condition and power relations in society (Giddens, 2012; Butler, 2003). From this, other categories develop, such as gender identity and expression and sexual orientation: the first refers to individual identification; the second to how the person presents themselves; the third to the affective-sexual orientation (Butler, 2003).

The present work mobilizes such categories under the Butlerian perspective, which comprises gender and sex itself, as an effect of naturalized reiterations, in constant construction, both at the individual level and in social relations. Despite their transitory character, it is clear that some of these naturalizations gain a social status of truth (Butler, 2003).

In this sense, male domination and compulsory heterosexuality stand out. The first, according to Bourdieu (1998), is a form of symbolic violence, that is, the imposition of certain meanings as legitimate, masking power relations that support it. In this case, the symbolic domination of the masculine over the feminine. The second is understood as institutions, structures of understanding, and practical guidelines that establish heterosexuality as the only coherent sexual orientation, assuming linearity: sex - gender identity - sexual orientation (Butler, 2003; Berlant, 2002).

This normative regulation falls on heterosexual people, as well as on lesbians, gays, bisexuals, transvestites, and transsexuals (LGBT), inducing the construction of masculinities and femininities ${ }^{6}$. However, it is clear that non-heteronormative gender identities and expressions suffer greater discrimination (Silva \& Barbosa, 2016; 


\section{Warner, 1993).}

In the health service, family environment, school, work, or on the streets, those who present characteristics and social practices that are "dissident" in relation to gender and other social norms suffer repression (Garcia, Mendonça-Magro, \& Leite, 2015; Sena \& Souto, 2017). It is also noticed that the trajectories of going/maintaining on the streets are related to gender "dissidences", articulated with other deviations, culminating in family conflicts (Campos \& Moretti-Pires, 2018).

The homeless population (HP) is understood as a heterogeneous group that has in common extreme poverty, broken or weakened family bonds, and the absence of regular conventional housing. They utilize public places and degraded areas as space for housing and subsistence, temporarily or permanently, as well as reception units for overnight stays or temporary housing (MDS, 2008). Family conflict is an important element of the HP trajectory, accounting for $29.1 \%$ of going to the streets, behind unemployment $(29.8 \%)$, and alcoholism/drugs (35.5\%) (Natalino, 2016).

There is a significant increase in the HP in the national and international scenario (Natalino, 2016; ONU, 2015). In 2016, there were approximately 101,854 homeless people (Hp) in Brazil, twice as much as in 2008 (Natalino, 2016; MDS, 2008). This population, in Brazil, is mostly male, black, with a low level of education, living for more than two years on the streets and precariously accessing health services, with urgencies and emergencies being the main doors of entry (MDS, 2008; ICOM, 2017; FIPE, 2015).

The first homeless study to address sexual orientation was the census conducted in the city of São Paulo, in 2015, in which about $91.1 \%$ of the Hp identified themselves as heterosexual and $8.9 \%$ as non-heterosexual (FIPE, 2015), corroborating with international studies (Keuroghlian, Shtasel, \& Bassuk, 2014; Stablein, 2017). Both groups are vulnerable due to living on the streets. Nonetheless, LGBT people suffer more violence, use more drugs, have more difficulty accessing health and social assistance services, and are more affected by diseases, when compared to heterosexuals (FIPE, 2015).

The research questions are: What are the relationships between gender and the social trajectory of homeless people? What are the impacts of gender relations on the access of Hp to public services? The objective of this article was to understand the relationship between gender constructions and the process of going/settling on the streets, as well as their effects on access to health services for Hp in the city of Florianópolis/SC.

\section{Methodological Route}

Qualitative research that comprises a set of practices that encompass the meanings attributed by individuals to their experiences. A social constructionist posture was adopted as an epistemological support and methodological procedures (Gergen \& Gergen, 2010; Spink, 2014).

The research was carried out between September 2017 and February 2018 in the streets of downtown Florianópolis/SC, the region with the highest concentration of Hp. In 2017, Santa Catarina's capital had 499 homeless people, $69 \%$ male and $31 \%$ female, with no data on gender identities or sexual orientation (ICOM, 2017).

To collect information, an ethnographic posture with daily observation was adopted (Spink, 2014). The researcher frequented daily, at different times, spaces used by homeless people in the city, initially to enter the field (Geertz, 1989), due to the difficulty of access, and later to maintain and reinforce bonds in the research development. Participants were selected from field contacts. Intentional sampling was used with the selection of Hp who had relevant experiences on the investigated theme (Rojas-Soriano, 2004).

For registration, a field diary was used, in which the researcher's perceptions about the spaces, actions, expressions, concerns, doubts, anxieties, and ideas arising from the interaction were written, in addition to reports exposed during the conversations (Spink, 2014). Information of $28 \mathrm{Hp}$ was registered.

After entering the field, semi-structured individual interviews were conducted with 2 lesbians, 2 gays, 3 heterosexual men, and 2 heterosexual women. These people had previously been contacted in informal research conversations and were selected for the experiences related to the theme.

The interlocutors were informed about the objectives of the study, signed and received a copy of the Free and Informed Consent Form; however, the vast majority saw no sense in this formalization.

The collection was carried out on sidewalks, benches, and marquees. The interviews were conducted in dialogues, and the interviewees were invited to tell their social trajectory. To direct the conversation, the research used the following topics: Reasons that took them to the street; Process of leaving home; Reasons that keep them on the street; Effects of gender expression on relationships in the street context. The interviews and field diary records 
were transcribed in full.

The analysis was carried out by describing and categorizing the discourse in three axes: going to the street; settling/maintenance on the streets; and relationship with health services. The narratives of LGBT and heterosexual people were analyzed separately within the three axes, presenting the existing intersections. Subsequently, a critical reflection was carried out on the meanings constructed by the Hp confronting it with gender, health, and homeless literature.

The study was submitted and approved, under protocol number 104963/2015, by the Ethics Committee in Research with Human Beings of the Federal University of Santa Catarina, according to CNS Resolution 466/12.

\section{Results and Discussion}

During the six months of the field research, twenty-eight Hp were known. Thus, this research's results were composed of the records in the field diary, derived from these experiences, and the nine interviews conducted with LGBT and heterosexual people living on the streets.

The profile of these interlocutors was composed mostly of male people (71.4\%), corroborating the proportion of men in the Brazilian (82\%) and Florianópolis (77.8\%) HP (MDS, 2008; ICOM, 2017). In relation to LGBT people, $14.3 \%(n=4)$ identified themselves as lesbian $(n=2)$ or gay $(n=2)$. However, they assumed the identities of "dyke" and "fag". A higher percentage of LGBT is noted in the present study when compared to the municipal census of São Paulo, in which $8.9 \%$ of the Hp identified themselves as non-heterosexual. However, this may be related to the focus on the gender relations of this research (FIPE, 2015).

\subsection{Trajectories of Going to the Streets}

Among the meanings built on the motivations for leaving home, it was noticed that the difference in family members' values on social gender expectations based on intrafamily conflicts and violence. The exacerbation of these events was the main trigger for going to the streets. Among lesbian women and gay men, aggressions occurred, culminating in cases of gender, physical violence, and being kicked out of the house.

"They wanted me to learn to like cock by force! I can't even talk about it much. It was my father and uncle who raped me... at home!" (Interlocutor 22)

"My grandmother didn't even want to hear about me being with other women... But for her, women have to like men and there's no way. Either change or live being beaten." (Interlocutor 23)

"You know, in my town, everything is very black and white... fagots don't have much whining. [...] At first, the mother tried to face me... except that the father was no longer... he excommunicated me from home." (Interlocutor 21)

It is noted that the previous scenarios of these homeless people were marked by heteronormative attitudes, considering only heterosexuality as acceptable. Supported by the discourses disseminated socially and corroborated by biomedical perspectives on the sexes, women and men could only be heterosexual, even if it does not suit the wishes of the interlocutors (Berlant \& Warner, 2002).

In the international literature, family conflicts are pointed out as a trigger for the departure of LGBT Hp, in general, motivated by the non-acceptance of gender identities (Keuroghlian, Shtasel, \& Bassuk, 2014; Mallet, Rosenthal, Keys, \& Averill, 2009). However, economic factors interfere in the process; poorer people are more likely to go to the streets (Schmitz \& Tyler, 2018).

For heterosexual women, social relations based on male domination, especially in the father figure, motivated controlling behavior and curtailed freedom to the point of causing them to leave home.

"I was 19 and had no choice in anything... I did just what they wanted. [...]. The old man was very jealous. Anyone who looked at me he already wanted to fight and then humiliated me at home, even called me a whore just because I was wearing shorts. [...] Then I saw that I had to run and I went to the street." (Interlocutor 26)

"It was the only way out for me and him [...]. There was no way to give food to my son, you know... or food or rent... It's sad to remember... When we went out on the street, they took him away from me." (Interlocutor 25)

A study with women living in the city of São Paulo relates going to the streets to three specific situations: violence suffered in the domestic/family context; insufficient income for their livelihood and that of their children; rupture of social bonds (Rosa \& Brêtas, 2015). The first and second situations demonstrate the effects of violence directed at women, sustained by the symbolic violence of male domination (Berlant \& Warner, 2002).

It is noticed that the gender expectations of "being a woman" motivate violence in the domestic environment, in 
the regulation of wives, daughters, sisters, and even mothers. Besides, this same symbolic system delegates the status of fragility and the responsibility of caring for children to women, given the predominance of single-parent families headed by women (Gonçalves, 2018). It is noteworthy that the small number of women on the streets, compared to men, is permeated by male domination, since the perception of fragility, attributed to women, causes only those who do not have a strengthened network or who break down with this perception of fragility to reach the streets.

For heterosexual men, not corresponding to the characteristics linked to the hegemonic masculinity imposed a process of constant suffering, which culminated in running away due to shame. In this sense, the normativity established by the reiteration of male domination also places men in a vulnerable situation, imposing the need to think of the concept of masculinity in the plural and observe the peculiarities of homeless men.

"Being a real man means being able to provide for the family... [...] I couldn't get a painting job anymore. And you've seen a betrayed man has no morals, it's a shame... it's just a joke [...]." (Interlocutor 12)

"After the woman asked for a separation, I had no reason to live anymore. For me, the family was everything... I spent everything I had on drugs and whoring and ended up here on the street." (Interlocutor 12)

Although the HP is mainly formed by men, the absence of discussion about the implications of masculinities (Connell \& Messerschimidt, 2013) in going to the streets is highlighted. However, it is identified that the trigger for family conflicts and going to the streets among men occurs in adulthood when the demands of "being a man" and becoming a provider intensify (Rocha, 2012).

It is noticed that the reason for leaving home varied with the gender identity of the Hp. While some were forced to leave and others left to avoid continuing violence and suffering. The effects of gender relations were presented as central and defining points in breaking bonds/going to the streets. However, this process was marked by disaffiliation, usually accompanied by socio-economic vulnerabilities that contributed to settling on the streets (Packer, Higa, Varga, Campos, \& Turato, 2015).

\subsection{Settling and Life on the Streets}

Despite the naturalization of living on the street as an imposition of social relations, it is also configured as resistance. In other words, action contrary to the control and violence suffered within the family, the State, and the school, which operate in a logic centered on male domination, privileging heterosexuality.

"It is not easy here [...]. But I do what I want and I'm feeling this way... but we help each other and respect each other... better than at home, right!" (Interlocutor 13)

"My mother even visits me sometimes... she knows that I like this life [...], it is dangerous but that I get used to it and I have many real friends... I'm going out one day but I won 't go home... and there are people in the "areas" that I stay in that make me stay around here." (Interlocutor 24).

The understanding of the street as a space that allows the existence for people for a long time subjected to violent processes in families is perceived in the narratives. As a new shelter, a space for escape from unsustainable situations with families is transformed into a place for building relationships and resistance (Cunha, Garcia, Silva, $\&$ Pinho, 2017). Despite the vulnerability experienced daily on the streets, deep social bonds are formed.

However, inhabiting the streets requires adaptation to the rules of this space, submitting to violence and territorial disputes. After knowing and adapting to the norms of the streets, people join the groups, starting to share experiences, bonds, and relationships of care and respect, something that did not exist in previous relationships. It breaks with the standard of the house as a place of protection, privacy and intimacy, resigning the public space (Andrade, Costa, \& Marquetti, 2014).

When using public space as a home, they are subjected to danger, publicity and, paradoxically, anonymity due to social invisibility (Souza, 2018). The condition of need that permeates life on the streets, as well as the adaptations made to the local culture, start to constitute the identity of these people, making them homeless (Andrade, Costa, \& Marquetti, 2014).

The effects of living on the streets on female and male bodies, whether due to biological differences or social constructions, present marked differences. Understanding gender identities on the street goes through the understanding of the influence of characteristics typical of living on the streets, such as: fluidity of bonds, different forms of violence, and the need to meet basic demands. Even though gender identity and sexual orientation have motivated people to go to the streets, a reconstruction of them is perceived in the new context, in a continuous and constant process of transformation and reiteration (Butler, 2003). 
Cis women living on the streets refer to menstrual periods as an obstacle: when they are unable to access sanitary pads and spaces for hygiene, they get bloody days or clean themselves in inappropriate places.

"At the end of the year the POP closed [...] you know, you know, when blood comes out... in those days I had to get some clothes and I went back there in the sea to take a shower... the luck is that it is summer." (Interlocutor 20)

The way public space and living on the streets are thought imposes specific conditions on them, due to physiological conditions and the need to seek alternatives to meet basic needs for hygiene and health (Giorgetti, 2014). Besides, the location, time, and day of operation of public devices often compromise access (Pinheiro \& Possas, 2018).

They are also the target of greed on the streets. The permanence in the public space causes many women, heterosexuals and lesbians, to be harassed and to suffer sexual violence by homeless men and police. In this sense, some women seek protection through a fixed relationship with homeless men who hold power in the "areas". However, others, especially lesbians, have characteristics of violent masculinities and associate with other Hp, forming groups to protect themselves.

"Here they respect me, you know! I don't even want to know, I push and do everything I can, if I need to take a stick and hit the guy on the head!" (Interlocutor 23)

"I always have a boyfriend, you know!? They take care of me and I also know how to take care." (Interlocutor 20)

Rosa \& Brêtas (2015), also found this impossibility for women to deny sexual relations on the streets. Nevertheless, they point out that the search for someone for protection is linked to friendships. The idea of protection in the masculine figure or performativity is imperative, corroborating the structured idea of male domination (Bourdieu, 1998).

In a study on masculinities among homeless people, Pinheiro and Possas (2018) identified that single women experienced the fear of violence and rape more intensely than those with a fixed relationship, who used masculine dispositions for protection, which the author calls displaced masculinities. The idea of coherence between sex, gender, and desire is questioned (Butler, 2003). One starts to think about performativities mediated by a complex social process, which in this case is related to protection and survival (Butler, 2003; Pinheiro \& Possas, 2018).

Those who identify themselves as gay are harassed "in the dead of night" by their street companions, mainly under the influence of drugs since this harassment comes from heterosexual men living on the streets who live together on a day-to-day basis.

"There is always someone wanting, they drink, smoke and come... They are needy, some even cry." (Interlocutor 21)

"There's a lot here, man... we need to fuck... some really abuse women and the guys who are more like women..." (Interlocutor 18).

It is noticed that despite the spatial difficulties, the Hp maintains sexual relations, with fixed partners or not, for pleasure. The studies on HP highlight sexual relations between men without identification as homosexuals, in addition to presenting gay characters and homosexual couples (Varanda \& Adorno, 2004; Langa, 2012; Costa, 2007). The shame of revealing these practices, secondary to heterocentric and sexist perceptions, stands out (Souza, 2018).

The street context is related to drug use. Consumption can be a reason for going to the streets or adapting to them. It was noticed in the present study that the use of drugs is carried out to stay awake, due to the insecurity of sleeping on the streets; to sleep, due to excessive consumption, and to forget about problems; and as a way to socialize.

"When I started sleeping on the street, I was very afraid, my father had raped me... I was afraid of everyone... Sometimes I used drugs to stay awake... I also used it to sleep... I used it until I blacked out and only woke up the other day." (Interlocutor 22)

"I got to the street only drinking cachaça... life here is hard, there is always someone doing their stuff and on drugs and then you are there and use it... I've used everything and it's hard to stop." (Interlocutor 30)

Unlike what was found in this article, Varanda and Adorno (2004) point out that drug use was identified as a way to censor the discomfort of poor hygiene. Packer, Higa, Varga, and Campos (2015), corroborating the perceptions found, suggest that entering drug consumption is part of adapting to the streets.

It was also found that drugs are used as bargaining chips and mediators for sexual relations.

"They know that I have sex with other men... Then when they want it really bad, they come to offer me a rock for 
a blowjob... they want to fuck my ass... I will not lie to you, sometimes I will go but I prefer women." (Interlocutor 12)

"Some women always come here in my tent, they already know that I have some change and rock." (Interlocutor 11)

In these relationships, usually under the influence of drugs, sexual practice is not only between men and women, as found in a study with crack users in the capital of Santa Catarina and a city in the west of the state (Zeferino, Fermo, Fialho, \& Bastos, 2017).

It is noted in the literature reports of female prostitution of the HP, something little registered in this work, despite the constant contact with what they call "exchanges" (Rosa \& Bretas, 2015). What is little debated, as they are cases "that are not openly commented on", according to Varanda and Adorno (2004), is male prostitution. On the streets of Florianópolis, it is a service usually provided to non-homeless people.

"I'm a man... I like women... on the street I started to be given a line by the guys. They pass by car and feel great and offer some money. When I go to hotels, I bathe before and after... sometimes it's in the car or in some squares. There are some that do almost fixed service." (Interlocutor 12)

"Are you seeing these guys sitting there on the bench? During the day they pretend they don't even see me and at night they want to. I've already fucked all their asses." (Interlocutor 7)

The practice of prostitution with non-homeless people points to a marked contradiction. At the same time, they have extremely close relationships during sexual intercourse, there is an invisibility behavior in other scenarios. Among non-homeless men, prostitution is justified by the financial return. However, it does not present this paradoxical relationship of visibility and invisibility (Prado-Júnior, Amaral, \& Barbosa, 2018).

This perception of invisibility is present not only in this situation. For example, although there are groups that come together to take food, clothes and offer opportunities to leave the street, this ends in these moments. In other dimensions, there is no relationship, only in the role of helping the one who needs (Cunha, Garcia, Silva, \& Pinho, 2017). Goffman (2011) considers this phenomenon of naturalization of people's place in the social context as civil inattention. In other words, this population's invisibility is not about their inexistence but about their existence in a defined and naturalized place.

The sexual practice among homeless heterosexual men is justified by the need for sex and the lack of women, unrelated to gender identity and expression or sexual orientation. Gay men are requested, however, there is also sex among the self-identified as heterosexual.

"As I am faggot when people get crazy and want to, there are a lot of people who lean on me to have some affection... I don't like it very much... there are some who are aggressive... And sometimes there are some who say they are macho, going to some corner and hiding in the tents." (Interlocutor 21)

Thus, when thinking about identities and expressions of gender and sexual orientation, one should consider the fluidity, uncertainty, and non-linearity between them. In this sense, it becomes coherent to dialogue with identities based on performativities that are defined and defined, are adjusted and readjusted according to the reiterations, possibilities, and intentionalities of those who perform (Butler, 2003).

Despite these homosexual relationships on the streets and the coexistence between different identities, strong discrimination against gays is perceived in the studies (Keuroghlian, Shtasel, \& Bassuk, 2014; Langa, 2012). It is noteworthy that even in a scenario of constant social exclusion, gender phobias present outside the streets reproduce, mainly against lesbian women, gay men and those who have sex with other men (Garcia, 2013). Thus, there are people who suffer double stigmatization: because they live on the street and because they are lesbians or gays.

Even in this scenario, the narratives point to a possibility of expressing different gender identities, with fewer strings than those previously on the streets.

"Here I can be who I am... I use my drugs, whenever I want, I have a flirt [...]" (Interlocutor 23)

"I'm fine, I want to leave here, but never to go home... but here I know I have to take care of myself and I do it like this, but it's better than before..." (Interlocutor 22)

"Being a fag on the street is not easy, but I prefer it than when I was at home... Here you do not have to report to anyone..." (Interlocutor 21)

As previously pointed out, the street conforms not only as an imposed situation but also as a space of resistance to violence suffered (Foucault, 1979). Despite the social exclusion experienced on the streets, it is noted that leaving 
home and staying on the streets allows for building less violent relationships and foreseeing a way out of the streets (Packer, Higa, Varga, Campos, \& Turato, 2015).

In this sense, supportive relationships among homeless people stand out, forming bonds that allow them to face and survive everyday situations. From these bonds, they share living spaces, seek income sources, and share food, drinks, and drugs (Andrade, Costa, \& Marquetti, 2014).

It was noticed during the research that the relationships created between them and with the street space are fundamental for maintenance on the street. It is noticed that in addition to the use of drugs, the street causes a feeling of freedom due to physical conformation, without walls, something that causes conflicts when returning to a home.

\subsection{Health Services}

Regarding Primary Health Care (PHC) and Clinics on the Street (CR), it is clear that this population does not have access to services. Besides ignorance of rights and past negative experiences, one of the main obstacles is self-concept. This means that many do not seek health services.

"I didn't even know that there was such a clinic for the homeless... at the health center I don't even go here, there are people who go and get kicked out! I'm ashamed, sometimes I get a bad smell and people know I'm homeless ..." (Interlocutor 23)

"I went there a few times and they kept me waiting... I still came back a few times, but one day they didn't let me in saying that there were a lot of people there and I never went back." (Interlocutor 22)

The material developed by the Ministry of Health to assist the homeless population (Ministério da Saúde, 2014) already pointed to the need to open the assistance network, especially the PHC to monitor this group. However, despite some positive experiences with the $\mathrm{CR}$, there is a need for progress in implementing the service and raising the awareness of professionals to adequate and contextualized care (Hino et al., 2018). However, the health needs of the homeless are notable, from basic care such as making and changing dressings, to cases of tuberculosis, HIV/AIDS, malnutrition, etc (Ministério da Saúde, 2014; Hino, Santos, \& Rosa, 2018).

The lack of adequate care in PHC, makes homeless people aggravate due to resolvable problems. Access to health services is due to urgency and emergency, only in severe cases or when they have a serious accident (Ministério da Saúde, 2014).

"When I'm sick I try to get by, I get a drug from an acquaintance... except that sometimes, only when I'm really bad, I almost die, I go to the emergency room." (Interlocutor 13)

"I go to the hospital, care has already been denied because I was undocumented and I have no address... It depends on who's there, you know..." (Interlocutor 21)

The expression of non-heterosexual gender was placed as an obstacle in the form of assistance in health and social assistance services. Prejudiced attitudes of professionals working in the services and other homeless people who share the space promote taking these people away (Langa, 2012).

"They must think that I have AIDS just by being on the street... They're already afraid of even getting close to you. Look there is a fagot, a guard at the health center told her friends. And another one who was with her said like this: it's a homeless fag get out of here!" (Interlocutor 21)

"I went to the POP and a guy sat next to me... he looked at me a little down! I already asked him what he wanted you, know, just like that... And he was laughing all the time and said: "Look, the dyke is going mad, she's going to beat me..." (Interlocutor 23)

When thinking about the street situation for LGBT people and analyzing gender relations, we deal with stories of glaring vulnerabilities, with health and social assistance services having little influence on modifying this process. There is great suffering of these people when dealing with stigmatization discourses, based on prejudice for the current condition. This is a challenge for the Brazilian health system and your specialized services and policies for homeless and LGBT people (Sena \& Souto, 2017; Hino, Santos, \& Rosa, 2018).

\section{Conclusions and Recommendations}

It is noted that gender relations are closely related to the process of disaffiliation, breaking family bonds, leaving home, and going to the streets. However, the effects of heteronormative patterns permeate life on the streets with effects on situations of violence, use of the body, and relationship with services of LGBT people.

The male domination present in the street context is perceived, and from it hierarchical and violent social relations 
are established against heterosexual women and LGBT people. Heterosexual men, despite perpetrating violence, also suffer when establishing their domination position.

In general, a street culture was perceived, immersed in a scenario of social, economic fragility, and crossed by gender relations. Despite the plurality, both in trajectories and objectives, it is clear that the population shares a current situation of adversity and builds new meanings for the street and their existences.

The health care of this population poses challenges to the Unified Health System (SUS), especially PHC, with the implementation of the CR and bringing these people closer to the services. It is clear that this population's precarious health conditions and the complexity of social relations on the streets require the articulation of public policies in the different sectors. Additionally, the need to approach the street population based on their needs is highlighted, considering the socio-economic context, gender relations, and needs arising from living on the streets.

In this sense, there is a need to review the focus of strategies for assisting HP, still focused on social hygiene, coercive actions, and "anti Hp" strategies to remove the population from the central regions. In addition, social assistance strategies should be rethought and contextualized from life on the streets.

Further studies are recommended to deepen the relationship between gender, Hp and access to public policies; the relationship between gender discrimination and going to the streets and staying there; and access to health services for Hp, with an emphasis on LGBT.

\section{Competing Interests Statement}

The authors declare that there are no competing or potential conflicts of interest.

\section{References}

Andrade, L. P., Costa, S. L., \& Marquetti, F. C. (2014). A rua tem um ímã, acho que é a liberdade: potência, sofrimento e estratégias de vida entre moradores de rua na cidade de Santos, no litoral do Estado de São Paulo. Saúde Soc, 23(4), 1248-1261. https://doi.org/10.1590/S0104-12902014000400011

Berlant, L., \& Warner, M. (2002). Sexo em Público. In: Jiménez, R. M. M. (Ed.), Sexualidades transgressoras (pp. 229-257). Barcelona, CT: Içaria Editora.

Bourdieu, P. (1998). A dominação masculina. Rio de Janeiro, RJ: Bestbolso.

Butler, J. (2003). Problemas de gênero: feminismo e subversão da identidade. Rio de Janeiro, RJ: Civilização brasileira.

Campos, D. A. \& Moretti-Pires, R. O. (2018). Trajetórias sociais de gays e lésbicas moradores de rua de Florianópolis (SC), 2016. Revista Estudos Feministas [online], 26(2), e45995. https://doi.org/10.1590/1806-9584-2018v26n245995.

Connell, R. W., \& Messerschimidt J. W. (2013). Masculinidade hegemônica: repensando o conceito. Revista Estudos Feministas [online], 21(1), 241-282. https://doi.org/10.1590/S0104-026X2013000100014

Costa, D. L. R. (2007). A rua em movimento: experiências urbanas e jogos sociais em torno da população de rua. Universidade de São Paulo, São Paulo, Brasil; 2007. Retrieved from https://www.teses.usp.br/teses/disponiveis/8/8134/tde-20122007-140625/pt-br.php

Cunha, J. G. D., Garcia, A., Silva, T. H. D., \& Pinho, R. C. D. (2017). Novos arranjos: lançando um olhar sobre os relacionamentos interpessoais de pessoas em situação de rua. Gerais: Revista Interinstitucional de Psicologia, 10(1), 95-108

FIPE - Fundação Instituto de Pesquisa Econômicas. (2015). Prefeitura Municipal de São Paulo. Pesquisa Censitária da População em Situação de Rua da Cidade de São Paulo. São Paulo, SP: FIPE.

Foucault, M. (1979). Microfisica do poder. Rio de Janeiro, RJ: Editora Graal.

Garcia, M. R. V. (2013). Diversidade sexual, situação de rua, vivências nômades e contextos de vulnerabilidade ao HIV/Aids. Temas de Psicologia, 21(3), 1005-1019. http://dx.doi.org/10.9788/TP2013.3-EE17PT

Garcia, M. R. V., de Mendonça-Magro, V. M., \& Leite, K. C. (2015). Discriminação e Violência Homofóbica Segundo os Participantes da $6{ }^{\text {a }}$ Parada Do Orgulho LGBT De Sorocaba-SP: subsídios para (re)pensar as $\begin{array}{lllll}\text { práticas educativas. } & \text { Cadernos de } & \text { Pesquisa, } & \text { 22(3), }\end{array}$ http://dx.doi.org/10.18764/2178-2229.v22.n3.p.42-58

Geertz, C. (1989). A interpretação das culturas. Rio de Janeiro, RJ: Guanabara Koogan.

Gergen, K. J., \& Gergen, M. (2010). Construcionismo social: um convite ao diálogo. Rio de Janeiro, RJ: Editora 
do Instituto NOOS.

Giddens, A. (2012). A transformação da intimidade: Sexualidade, Amor e Erotismo nas Sociedades Modernas. São Paulo, SP: Editora UNESP.

Giorgetti, C. (2014). Moradores de rua: uma questão social? São Paulo, SP: Fapesp.

Goffman, E. (2011). Ritual de interação: ensaios sobre o comportamento face a face. Petrópolis, RJ: Vozes.

Gonçalves, C. D. J. M. (2018). Casamento, Gênero e Violência Doméstica e Familiar Contra a Mulher no Brasil. Um Olhar Retrospectivo. Revista Jurídica Luso-Brasileira, 4, 315-318.

Hino, P., Santos, J. O., \& Rosa, A. S. (2018). People living on the street from the health point of view. Revista Brasileira de Enfermagem, 71(1), 684-692. https://doi.org/10.1590/0034-7167-2017-0547

ICOM - Instituto Comunitário Grande Florianópolis. (2017). Diagnóstico Social Participativo da População em Situação de Rua na Grande Florianópolis. Florianópolis, SC: ICOM.

Keuroghlian, A. S., Shtasel, D., \& Bassuk, E. L. (2014). Out on the street: a public health and policy agenda for lesbian, gay, bisexual, and transgender youth who are homeless. American Journal of Orthopsychiatry, 84(1), 66-72. https://doi.org/10.1037/h0098852

Langa, E. N. B. (2012). Pessoas que habitam as ruas em Fortaleza nos circuitos da vulnerabilidade e exclusão: identidades em construção nas trajetórias e percursos. Universidade Federal do Ceará, Ceará, Brasil. Retrieved from shorturl.at/fuDY1

Mallet, S., Rosenthal, D., Keys, D., \& Averill, R. (2009). Moving out, moving on: young people's pathways in and through homelessness. London: Routledge.

MDS - Ministério de Desenvolvimento Social. (2008). Pesquisa Nacional sobre a População em Situação de Rua. Brasília, DF: MDS.

Ministério da Saúde. (2014). Saúde da população em situação de rua: um direito humano. Brasília, DF: Ministério da Saúde.

Natalino, M. A. C. (2016). Estimativa da População em Situação de Rua no Brasil. Rio de Janeiro, RJ: Ipea.

ONU - Organização das Nações Unidas. (2015). Informe de la Relatora Especial sobre una vivienda adecuada como elemento integrante del derecho a humano. Genebra: Conselho de Direitos Humanos.

Packer, M. P., Higa, R., Varga, C. R. R., Campos, C. J. G., \& Turato, E. R. (2015). "Virei um mendigo": vivências de ex-moradores de rua acolhidos em uma instituição confessional brasileira. Revista de Enfermagem da UFSM, 5(1), 69-80. https://doi.org/10.5902/2179769212964

Pinheiro, Z. D. A. C., \& Possas, L. M. V. (2018). Centro pop: quando uma política pública incomoda. Revista do Instituto de Politicas Públicas de Marília, $4(1), \quad 35-54$. https://doi.org/10.33027/2447-780X.2018.v4.n1.04.p35

Prado-Júnior, V. I., do Amaral, F. B., \& Barbosa, Y. M. (2018). Epistemologia do território: a prostituição masculina em Goiânia. Revista Brasileira de Gestão Urbana, 10(2). https://doi.org/10.1590/2175-3369.010.002.AO14

Rocha, D. E. H. (2012). Rumo à vida nas ruas: trajetórias sociais de moradores de rua em Guaratuba/PR. Universidade Federal do Paraná, Paraná, Brasil. Retrieved from https://acervodigital.ufpr.br/handle/1884/39468

Rojas-Soriano, R. (2004). Manual de pesquisa social. Petrópolis, RJ: Editora Vozes.

Rosa, A. D. S., \& Brêtas, A. C. P. (2015). A violência na vida de mulheres em situação de rua na cidade de São Paulo, Brasil. Interface-Comunicação, Saúde, $\quad$ Educação, $19, \quad 275-285$. https://doi.org/10.1590/1807-57622014.0221

Schmitz, R. M., \& Tyler, K. A. (2018). The complexity of family reactions to identity among homeless and college lesbian, gay, bisexual, transgender, and queer young adults. Archives of Sexual Behavior, 47(4), 1195-1207. https://doi.org/10.1007/s10508-017-1014-5

Sena, A. G. N., \& Souto, K. M. B. (2017). Avanços e desafios na implementação da Política Nacional de Saúde Integral LGBT. Tempus Actas de Saúde Coletiva, 11(1), 09-28. https://doi.org/10.18569/tempus.v11i1.1923

Silva, L. V., \& Barbosa, B. R. S. N. (2016). Sobrevivência no armário: dores do silêncio LGBT em uma sociedade de religiosidade heteronormativa. Estudos de religião, 30(3), 129-154. 
http://dx.doi.org/10.15603/2176-1078/er.v30n3p129-154

Souza, F. K. G. (2018). A margem da invisibilidade: uma pesquisa sobre a compreensão do morador de rua da orla de Macapá de sua inclusão social. Pey Këyo, 3(1), 34-56.

Spink, M. J. P. (2014). A produção de informação na pesquisa social: A produção de informação na pesquisa social. Rio de Janeiro, RJ: Centro Edelstein de Pesquisas Sociais.

Stablein, T. (2017). Estimating the Status and Needs of Homeless LGBT Adolescents: Advocacy, Identity, and the Dialectics of Support. In: P. N. Claster, S. Blair (Eds). Gender, Sex, and Sexuality Among Contemporary Youth (pp. 23-41). Bingley: Emerald Publishing Limited.

Varanda, W., \& Adorno, R. D. C. F. (2004). Descartáveis urbanos: discutindo a complexidade da população de rua e o desafio para políticas de saúde. Saúde e Sociedade, 13, 56-69. https://doi.org/10.1590/S0104-12902004000100007

Warner, M. (1993). Fear of a queer planet: Queer politics and social theory. Minnesota: University of Minnesota Press.

Zeferino, M. T., Fermo, V. C., Fialho, M. B., \& Bastos, F. I. (2017). Semelhanças e contrastes nos padrões de uso de crack em Santa Catarina, Brasil: capital vs Meio Oeste. Ciência \& Saúde Coletiva, 22, 97-106. https://doi.org/10.1590/1413-81232017221.18342016

\section{Copyrights}

Copyright for this article is retained by the author(s), with first publication rights granted to the journal.

This is an open-access article distributed under the terms and conditions of the Creative Commons Attribution license (http://creativecommons.org/licenses/by/4.0/). 